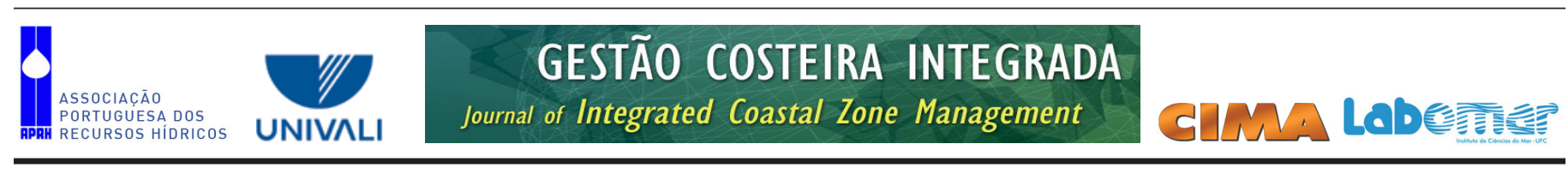

http://www.aprh.pt/rgci/pdf/rgci-407_Angelelli.pdf | DOI:10.5894/rgci407

\title{
Some remarks on Mangroves in the Lesser Antilles *
}

\section{Algumas reflexões sobre manguezais nas Pequenas Antilhas **}

\author{
Pierre Angelelli ${ }^{\circledR, 1}$, Pascal Saffache ${ }^{2}$
}

\begin{abstract}
During the past thirty years the surface of mangrove swamps in the Lesser Antilles has globally decreased over twenty percent. The phenomenon is worldwide spread but the Lesser Antilles' issues remain noteworthy because, due to the small size of these islands, prejudices on the mangrove swamps may have significant impacts. This paper starts to address some methodological remarks about statistics concerning mangroves (before the nineties, long-term data are incomplete and they impede a good estimate of the evolution of this ecosystem) and is mainly divided in two parts. In the first part, we briefly recall the importance of mangrove swamps in the Lesser Antilles. Despite the different physical characteristics of these islands, mangroves appear from several points of view as one of the common feature in these islands. Quantitatively, from 1980 to 2010, the area occupied by mangroves has regressed in the Lesser Antilles and in the world in general. Mangroves were soon disqualified owing to their inaccessibility and unhealthiness. Furthermore, deprived of their traditional functions, they have been progressively marginalized with economic development and rising living standards in small islands economies notwithstanding their positive role as an ecosystem. Highlighted since the 1980s, this role appears particularly evident in the field of marine resources and protection against hurricanes and tsunamis, but also to help restore the quality of coastal waters and biodiversity. In the second part of this paper, we wonder about the paradox faced by the inhabitants of the Lesser Antilles. On the one hand they really cannot prevent major natural threats on their wetlands like global climate change, hurricanes, earthquakes, volcanoes or tsunamis. And on the other hand, due to their territorial and political scale, these small islands should be able to act against local anthropogenic threats i.e. deforestation, household effluents, agriculture, urbanization, tourism, etc. Indeed, the Lesser Antilles islands have adopted the principles of ecosystem protection and integrated development of coastal areas (including various international conventions in this area). The land use policy, the urban planning, the building on the coastline or next to the mangroves are theoretically under public control. But the paradox is that effective provisions and outcomes are often weak against direct anthropogenic threats even if local solutions do not seem to be out of reach. We give a few typical examples illustrating the damage to mangroves in these islands today whatever the political status or the administrative organization. We conclude by considering that the case of mangroves in the Lesser Antilles may be a good illustration of the economic problem posed by the management of the commons. Shortly, the protection granted to goods depends on the value of goods. As for us the continuous decrease of mangrove surfaces reflects the lack of recognition of their value at every sense of the word. Even outside the market system, the recovery and the protection of mangrove swamps should first involve the determination of their explicit economic value.
\end{abstract}

Keywords : Caribbean islands, commons, mangrove swamps, social opportunity cost, wetlands.

\section{@ - Corresponding author}

1 - Centre d'Etude et de Recherche en Economie, Gestion, Modélisation et Informatique Appliquée - Centre for research and studies in economics, management, modeling and applied computer science (CEREGMIA - EA 2440) - Université des Antilles et de la Guyane (The University of the French West Indies and Guiana), Campus de Schoelcher, BP 7207, 97275 Schoelcher Cedex, Martinique (FWI). E-mail: pierre.angelelli@martinique.univ-ag.fr

2 - Université des Antilles et de la Guyane (The University of the French West Indies and Guiana), Campus de Schoelcher, BP 7207, 97275 Schoelcher Cedex, Martinique (FWI). E-mail: pascal.saffache@martinique.univ-ag.fr

* Submission: April 6, 2013; Evaluation: May 20, 2013; Reception of revised manuscript: August 17, 2013; Accepted: October 7, 2013; Available on-line: December 2, 2013 


\section{RESUMO}

Nos últimos 30 anos a superfície coberta por manguezais nas Pequenas Antilhas diminuiu vinte por cento. O fenómeno embora generalizado é notável nas Pequenas Antilhas, isto porque devido ao pequeno tamanho destas ilhas os danos nos manguezais podem ter impactos significativos. Neste artigo são abordadas de início algumas questóes metodológicas sobre as estatísticas relativas aos manguezais (antes da década 1990 os dados são incompletos e impedem uma boa estimativa da evoluçáo do ecossistema) e divide-se em duas partes. Na primeira parte, recordamos brevemente a importância dos manguezais nas Pequenas Antilhas. Apesar das diferentes características físicas destas ilhas, os manguezais aparecem como uma das características comuns nessas ilhas. Em termos quantitativos, entre 1980 e 2010, o espaço ocupado por manguezais regrediu mais rápido nas Pequenas Antilhas do que a média mundial. Os manguezais foram então rapidamente desclassificado pela sua inacessibilidade e insalubridade. Além disso, privados de suas funçóes tradicionais foram progressivamente marginalizados relativamente ao desenvolvimento económico e padróes de vida das pequenas economias insulares apesar do seu papel ambiental como ecossistemas prestadores de serviços. Desde os anos 1980 , esse papel de prestadores de serviços ecossistémicos fica particularmente evidente em matéria de recursos marinhos e da protecção contra furacóes e tsunamis como também para a restauração da qualidade das águas costeiras e da biodiversidade. Na segunda parte deste trabalho, questiona-se sobre o paradoxo enfrentado pelos habitantes das Pequenas Antilhas. Por um lado, eles não podem evitar as principais ameaças naturais nestas áreas húmidas, como a mudança do clima, furacóes, terramotos, vulcóes e tsunamis. Por outro lado, devido à sua dimensão territorial e política, estas pequenas ilhas devem ser capazes de agir contra ameaças antropogénicas, ou seja locais de desflorestamento, efluentes domésticos, agricultura, urbanização, turismo, etc. Na verdade, as Pequenas Antilhas adoptaram os princípios da protecção dos ecossistemas e a gestão integrada das zonas costeiras (incluindo diversas convençôes internacionais nesta área). A politica de uso do solo, o planeamento urbano, com base na zona costeira ou próximo aos manguezais estão teoricamente sob controlo público. O paradoxo é que mesmo com normas eficazes e bons resultados na aplicação das mesmas as ameaças antropogénicas sobrepóem-se. São ainda ilustrados alguns exemplos dos danos infligidos aos manguezais nas ilhas independentemente do estatuto politico ou a organização administrativa destas. Conclui-se que o caso dos manguezais nas Pequenas Antilhas pode ser uma boa ilustração do problema económico da gestão dos bens comuns. Brevemente, a proteç̧ão concedida aos bens depende do valor dos bens. A diminuição continua das superfícies de mangue (e sua recuperação e protecção) reflecte a falta de reconhecimento de seu valor em todos os sentidos da palavra. Mesmo fora do sistema de economia de mercado, a recuperaçáa e a proteç̧ão de manguezais exigem previamente a determinação de seu valor económica explícito.

Palavras-chave : Ilhas do Caribe, bens comuns, manguezais, custo de oportunidade social, zonas húmidas.

\section{INTRODUCTION}

During the past thirty years the surface of mangrove swamps in the Lesser Antilles has globally decreased over twenty percent. Even if the phenomenon is worldwide spread and then could be seen as quite common (FAO, 2007a: 9; FAO, 2010:30), the Lesser Antilles' issues remain noteworthy. Indeed, due to the small size of these islands, prejudices on their mangrove swamps have even more significant impacts. Therefore it is expected that these islands take measures to prevent the damages made on mangroves and their extinction.

This paper addresses the following items. First, we briefly recall the importance of mangrove swamps in the Lesser Antilles. Second, we wonder about the paradox faced by the inhabitants of these islands: clearly, they cannot prevent major natural threats on their wetlands (earthquakes, volcanoes, hurricanes, tsunamis, climate change), but they can act against the anthropogenic ones (deforestation, household effluents, agriculture, urbanization, tourism, etc.). The paradox is that effective provisions and outcomes often lack against modern direct anthropogenic threats even if local solutions are not out of reach. We conclude by considering that the case of mangroves in the Lesser Antilles might be a good illustration of the economic problem posed by the management of the commons.

\section{Temporal development and methods.}

Long-term global data are incomplete (Alongi, 2002:334) or lacking concerning the areas of mangrove swamps (changing as the time passes by). This fact only allowed a clear estimation of the deteriorations caused in this ecosystem from the beginning of the 1990s (FAO, 1994:511; Farnsworth \& Ellison, 1997:332).

The first evaluations of forest global resources led by the Food and Agriculture Organization of the United Nations FAO (FAO, 1948; FAO, 1957; FAO, 1958; FAO, 1963) hardly mention mangrove swamps. For instance, the word "mangrove" does not appear in the first document written in 1948. It does appear once in the one written in 1957 but without quantitative or qualitative data. The word appears twice in the version of 1958 in notes about Borneo and Gambia, and there still is a poor statistic data. And it does not exist in the document of 1963.

In the 1970s, not a single global evaluation is carried out by the FAO. Only few regional surveys were made almost outside the Organization (Europe, Asia and Far East, South America, Africa) Adrian Sommer's study commissioned by FAO only mention the word " mangrove " twice, without linking it to any data... However, the concept of ecosystem, speaking about mangrove swamps, arises in scientific literature (Lugo, 1980). And even if there are not many data about them at that time, mangrove swamps are beginning to be regarded as a natural resource from the point of view of environmental protection (Odum et al., 1982: 74-64; Christensen, 1983:2).

From 1980, the FAO has undertaken a regional evaluation on tropical forests in Asia, Africa and America. On this occasion, a particular attention was granted to the mangrove swamps (Lanly, 1982). Not only the word appears thirteen times in the document, but it is also treated as an 
ecosystemic issue: "One category of closed broadleaved forest merits particular attention, partly because of its products but especially for the particular services that its renders. The category is that of the mangroves which are, unfortunately, for the most part, subject to degradation and elimination processes especially through over-logging for firewood and small wood and for extraction of tannin". Besides, the deterioration phenomenon in its actual meaning is defined: "the degradation, under different forms, particularly of open formations, [is] deriving mainly from buman activities such as over-grazing, overexploitation (for firewood in particular), repeated fires, or due to attacks by insects, diseases, plant parasites or other natural causes such as cyclones, (which can cause considerable damage to trees) [...] The processes of degradation may, in their final stages, result in deforestation [...].» Then, the document issued in 1982 presents a first official estimate of the surfaces occupied by the mangrove swamps. Concerning the Caribbean islands, the member countries of the CARICOM have 236000 hectares of mangrove swamps whereas the other countries of the Caribbean have 597000 hectares. The total (833000 hectares) is in accord with the data gathered by the FAO since 1980.

According to the global forest resources assessment and to the new importance granted to the mangroves, the nineties appear to be a transition period allowing the FAO to adjust their goals with the general principles established in 1992 during the Rio Summit. It also was an occasion for the FAO to change its methods. The promoting of the forest is enforced with the will of going on with the sustainable development and keeping the biological diversity safe, as declared in the Agenda 21, chapter 11 against the deforestation and chapter 17. A more precise inventory of surfaces and the identification of the services given by such an ecosystem have led the FAO to combine statistic data from the member States to modeling, and the use of images from satellite. Following the same way, the International Society for Mangrove Ecosystems, a non-governmental organization created in 1990, issued the Charter for Mangroves (ISME, 1992) and the FAO also established a process to manage mangroves (FAO, 1994).

These last elements characterize the current assessment of mangrove swamps in relation with the global forest resources (FAO, 2001).

Data. Globally, mangrove areas were about 18.8 millions of hectares in 1980; 16.9 in 1990; 15.7 in 2000 and 15.6 in 2010 (FAO, 2007a:9 ; FAO, 2010a:30), that is to say a decrease of $17 \%$.

The FAO data about the large area "North America and Central America" (FAO, 2007b:31 \& Tab.10; FAO, 2010a:30 \& Tab.2.8) highlight the following development: 2.95 million of hectares in 1980; 2.59 in $1990 ; 2.35$ in 2000 and 2.38 in 2010 , that is to say a decrease of $24 \%$.

Lesser Antilles perimeter. In this paper about the Lesser Antilles we choose the perimeter determined by the FAO (FAO, 2001:Chap. 36): "The Lesser Antilles [are] the Virgin Islands, Saint Kitts and Nevis, Antigua and Barbuda, Montserrat, Guadeloupe, Dominica, Martinique, Saint Lucia, Saint Vincent and the Grenadines, Barbados, and Grenada".

\section{THE IMPORTANCE OF MANGROVES IN THE LESSER ANTILLES}

\subsection{Mangroves are a common feature in the Lesser Antilles with different characteristics}

\subsubsection{The Lesser Antilles islands have different physical characteristics}

Situated on the East part of the Caribbean Sea, they are divided in two geomorphological sets: the so-called "higher" ones can be associated at the same time to a xeric environment or a hygrophilous one. They often look like "high savannah". Their margins are bordered by a sedimentary volcanoclastic strip (which color varies from shiny black to light grey according to the minerals and the proportion of bioclastic sediments). It is the case in Dominica, Martinique, St.Lucia, Montserrat and St.Vincent. We can notice that 11 islands of the Lesser Antilles have an active volcano (i.e. from the smallest to the largest: Saba, St.Eustatius, Dominica, Nevis, Montserrat, St.Kitts, Grenada, St.Vincent, St.Lucia, Martinique and Guadeloupe) (Lesales, 2007).

The islands which are "lower" (flat) do not allow xeric vegetation and/or mesophilic vegetation because of their karst bedrock constitution. They are surrounded by white sandy beaches like in the US and British Virgin Islands, Saint-Martin, Saint-Barthelemy and the Grenadines.

These two types are sometimes near one another just like in Guadeloupe, where the Basse-Terre is "higher" and the Grande-Terre is "lower".

Whatever the geological origin of the islands is, their coastlines are never straight. And so, in the crevices of calcareous shores ("lower" islands), sediments impair themselves and turn into clay. On the volcanic sides ("higher" islands), the runoff of rain moves slight particles which accumulate at the bottom of slopes, in spaces more confined because of gravity. Earthy substrates that are propitious to the formation of mangrove swamps appear.

"Lower" and "higher" islands also have different rainfall regimes which affect their natural potential especially regarding the forests and mangroves evolution. Thus, lower islands basically have a dry climate (Virgin Islands, Anguilla, Antigua \& Barbuda, Saint-Martin, Saint-Barthelemy, Barbados, the Grenadines, etc.) and have a vegetal regeneration weaker than the higher islands (Saint-Kitts, Montserrat, Guadeloupe, Dominica, Martinique, St.Lucia, St.Vincent) (Lugo et al., 1981:320).

\subsubsection{Mangroves are a common feature in the Lesser Antilles}

Mangroves are one common feature in the Lesser Antilles among others like coral reefs and herbarium.

Forests with particular characteristics. Mangroves' forests have particular characteristics (Saffache, 2002). They are halophilic and they only grow in the back of bays, in ponds or on rivers borders. According to their kind of roots, these forests filter turbid waters and keep sediments. That causes the progradation of the shore. Seawards, the sandy coves are bordered by fringing reefs and situated farther off the barrier reefs present an exceptional biodiversity. These two ecosystems (mangroves and coral reefs) are among the more abundant in the world. 
Since the beginning of the colonization of the Lesser Antilles, mangrove swamps, called at that time mangles, have caught Europeans' attention because of their tangled roots - real maze - and their adaptation to salt water (du Tertre, 1667:167; Thibault de Chanvalon, 1763:14-15; Monnier, 1828:88-89).

Mainly located on the coasts, these forests are governed by three factors: the climate (air temperature higher than 18 degrees Celsius and temperature range smaller or equal to 5 degrees), the tides (mangroves grow mainly in the intertidal zone) and the salinity (rain water runoff and rivers' flow).

Because mangroves are basically on a muddy substrate, sometimes very liquid, mangrove trees adapted and now compose the dominant plant life. Mainly, two sorts of trees are spread in that environment: Rhizophora and Avicennia. The Rhizophora, for example, have their roots looking like stilts with multiple arches and making them higher in the mud. These physiognomic characteristics also allow them to resist to the erosion of tides. The Avicennia have a different roots structure. Instead of being in the air, the roots grow in straight lines under the mud. They emerge in a sporadic way thanks to little turgid protuberances, also called "pneumatophores", which are in charge of respiratory exchanges with the atmosphere. These roots stabilize the muddy substrate and filter turbid water keeping terrigenous sediments. That is why shores filled with mangrove trees are in progradation phase in general. However, the two types (Rhizophora and Avicennia) are very vulnerable because they breathe through openings - the lenticels - situated on their roots.

Mangroves are a shelter to a numerous and diverse fauna and thus condense an important part of wildlife resources of the region.

\section{A presence in each island of the Lesser Antilles.}

Quantification. Quantitative data about the mangrove swamps and their recent development in the Lesser Antilles are completed as follows (See Table 1).

Nowadays, the mangroves occupy about 1900 hectares in Martinique and 2950 hectares in Guadeloupe (FAO, 2007a:31). However, these coastal forests do not always have the same physiognomy. In Antigua \& Barbuda, for instance, not only they expand on 700 hectares (knowing that the total land area of these two islands is $442 \mathrm{~km} 2$ ) but they are

Table 1. Mangrove surfaces in the Lesser Antilles from 1980 to 2010 (in hectares).

Tabela 1. Superficies dos manguezais nas Pequenas Antilhas 1980-2010 (em hectares).

\begin{tabular}{|c|c|c|c|c|c|}
\hline & $1980^{a}$ & $1990^{a}$ & $2000^{a}$ & $2005^{a}$ & $2010^{b}$ \\
\hline Anguilla (UK) & 90 & 90 & 90 & 90 & 90 \\
\hline Antigua \& Barbuda & 1570 & 1200 & 850 & 700 & 700 \\
\hline Barbados & 30 & 16 & 7 & 4 & 7 \\
\hline British Virgin Islands (UK) & 660 & 630 & 590 & 570 & 554 \\
\hline Dominica & 12 & 10 & 10 & 9 & 9 \\
\hline Grenada & 295 & 260 & 230 & 215 & 179 \\
\hline Guadeloupe (FR) & 3000 & 2990 & 2960 & 2950 & $2950^{\circ}$ \\
\hline Martinique (FR) & 1900 & 1900 & 1800 & 1800 & 2023 \\
\hline Montserrat (UK) & 5 & 5 & 5 & 5 & 5 \\
\hline The Netherlands Antilles (NL) ${ }^{d}$ & 1140 & 1100 & 1000 & 1000 & 1180 \\
\hline St.Kitts \& Nevis & 85 & 80 & 75 & 70 & 14 \\
\hline St.Lucia & 200 & 200 & 200 & 200 & 164 \\
\hline St.Vincent \& the Grenadines & 55 & 51 & 50 & 50 & 37 \\
\hline US Virgin Islands (US) & 350 & 320 & 200 & 150 & 110 \\
\hline Total Lesser Antilles & 9392 & 8852 & 8067 & 7813 & 8022 \\
\hline
\end{tabular}

Sources : Authors, based on FAO data.

Nota:

a) data FAO, 2007: tab.10.

b) data FAO, 2010 : Global Forest Resources Assessment 2010 - Country Reports FRA2010/138, Rome.

c) The Guadeloupe national report 2010 Guadeloupe prepared for the FAO counts 7455 ha of mangrove swamps (data 2008) and 7400 ha (data 2002). The FAO keeps 2950 ha

c) The Guadeloupe national report 2010 Guadeloupe prepared for the FAO counts 7455 ha of mangrove swamps (data 2008) and 7400 ha (data 2002). The FAO keeps 2950 ha.

d) Until the 10/10/2010: Curaçao, Bonaire, Saba, St.Eustatius and St.Maarten. 
also dense and very thick ( 40 meters high). In many other islands, they are situated in smaller areas and their vertical growth is restricted: less than 20 meters in general: 90 ha in Anguilla which has a $91 \mathrm{~km} 2$ total land area; 7 ha in Barbados (403 km2); 9 ha in Dominica (751 km2); 179 ha in Grenada (344 km2); 5 ha in Montserrat (102 km2); 14 ha in St.Kitts \& Nevis (261 km2); 164 ha in St.Lucia (616 $\mathrm{km} 2) ; 37$ ha in St.Vincent and the Grenadines (389 km2).

Table 1 shows problems of method that provoke incomplete data: the data first come from independent States and then are subject to adjustment by the FAO. They are often unclear second-hand elements taken from monographic surveys or ancient assessments. Plus, the slow improvement of field surveys imposes adjustments that disturb the estimation of changes: i.e, recent statistics could reveal real evolutions (mangroves surface's increase or decrease) as well as flaws in the ancient measures (Valiela $e t$ al., 2001:807-808; Tab.1).

Guadeloupe that was supposed to have 9800 ha in the 1940's (Stehlé, H. 1945 - Forest Types of the Caribbean Islands, Part. I. Caribbean Forests, 6, Suppl., quoted by Ellison \& Farnsworth, 1999:552) seems to have lost 4800 ha from that time to 1980 (3000 ha), then 40 ha from 1980 to 2000 (whereas the non-corrected data given by the French government to the FAO state 7455 ha (FAO, 2010:25, 2930)). In Martinique, the surface occupied by mangrove has increased by 400 ha between 1940 and 1980, moving from 1500 ha (Ellison \& Farnsworth, 1996:551-552) to 1900 ha. In other words, it is supposed to have been reduced by 1100 ha between 1940 and 1980 moving from 3000 ha (Revert, 1949:174) to $1900 \mathrm{ha}$, and subsequently it seems to decrease at the beginning of the 2000's and to increase again at the end of it. Even though the values oscillate between 1840 ha and 2100 ha (FAO, 2010:8-9, 13), despite the buildings and the extensions of ports, airports, highways and commercial areas for 20 years, the data furnished by the French government certify the surface is 2023 ha in 2010 in Martinique.

On Grenada island, 70\% of the mangrove swamps have apparently been destroyed by the cyclone Ivan in September 2004 (OECS, 2005:66-70). However, there is no sign of any damages in the FAO statistics (FAO, 2007a).

The apparent accuracy of data (and evolutions) must not be trusted. In reality, ancient data can be imprecise but it is also the case for recent values that are extrapolated from the ancient ones.

Qualification. Highlighted because of their physical characteristics, mangrove swamps were soon disqualified by their inaccessibility and unhealthiness (Monnier, 1828:8889; Revert, 1949:21).

Gradualdisappearance of traditionalutilization. Traditional uses of mangrove swamps are well known. (Christensen, 1983:2; Vasques et al., 2011:157-159). We refer also to the synthesis carried out by FAO in Mangrove Forest Management Guidelines (FAO, 1994:45-87). As noted above, the human use of mangroves is old but variable in space and time. It is a way of life that has disappeared in most of the Lesser Antilles, and with it the threat (limited) that are (were) traditional human uses of mangroves vanished. In this context of "direct use" (Vasques et al., 2011:157-159), mangroves contributed to energy (firewood and charcoal), the supply of various materials construction (roofs, ceilings, walls, floors, fences, etc..), fishing (boat, fishing gear, tannin for dyeing nets, etc.), food (fruits, honey, plants infuse, fish, shellfish, game, etc.), to various domestic purposes (tools, oils, toys, traditional medicines, etc.) but also to garbage dumps.

Marginalization of mangroves. Deprived of their traditional functions, mangroves swamps have been marginalized with economic development and rising living standards. In the context of the Lesser Antilles, and especially regarding the mangroves, "the preservation of the environment is perceived as a luxury, and tourism development often as a priority" (Klein, 2003). So, the rejection of mangroves seems deeply rooted in individual, collective or even political behavior. This probably affected their conservation and allowed "ecocides" until recently (Malsa, 2008:101-104).

French geographer Eugene Revert (1895-1957) quoted by Judith Klein (Klein, 2003) reflected his time and probably unintentionally foreshadowed the "all-tourism" by the opposition between mangroves and pristine beaches (Revert, 1949:21).

However, the ability of ecosystems to produce resources and "ecosystem services" has begun to be acknowledged only recently (Odum et al., 1982 40-76; Costanza and Folke, 1996:17-18). Yet often we can apply concerning the mangroves the formula of Costanza and Folke "In many cases, what we think of as a waste resources are in the wrong place" (Ibid., 24).

\subsection{A remarkable interaction between natural factors}

\subsubsection{Mangroves in the Lesser Antilles are threatened by many natural factors}

Mangroves are threatened by natural phenomena (possibly indirectly anthropogenic) beyond the control of populations of the Lesser Antilles.

\section{Air temperature, volcanic eruptions, earthquakes, tsunamis.}

Elevation of long-term temperature of the air. This phenomenon itself (apart from its effects caused like rising sea level, precipitation and storminess) has an impact on mangroves. An increase in the average temperature of the air (fast enough to prevent adaptation) engages the survival of mangroves swamps from $38{ }^{\circ} \mathrm{C}$ to $40{ }^{\circ} \mathrm{C}$ (photosynthesis stop, leaf fall, tree mortality, soil decomposition with emission of methane, carbon dioxide and hydrogen sulfide) (Field, 1995:78; Ellison, and Farnsworth, 1996:556-557). Whether the Lesser Antilles knew such average temperatures, it is likely that other problems would arise in adaptation or survival of the species (including human) relegating the survival of mangroves in the background.

Volcanic eruptions. We have seen that the Lesser Antilles were partly composed of volcanic islands. For each of the 11 volcanic islands, Lesales (2007) recalls the "volcano exposure index" which reports the number of active volcanoes on the land area of the island (the higher the index is (e.g. Saba), the lesser the areas are sheltered). Despite their impact on mangroves, no measure of preventive protection of these areas has been taken in the Lesser Antilles, or any remedial 
measure (the case of Montserrat Soufriere in 1995). As for the temperature rise of the air, the eruptive episodes - moreover little predictable - in the Lesser Antilles refer to other emergencies beyond survival or rehabilitation of mangroves swamps.

Earthquakes and tsunamis. Just as volcanic eruptions, earthquakes and tsunamis are major phenomena that can cause the loss of mangrove areas, including soil liquefaction during earthquakes.

Climate change. The Lesser Antilles are particularly vulnerable to certain possible manifestations of climate change, such as the sea level general rise, flooding, increased salinity of coastal environments or increased frequency or intensity of hurricanes (Snedaker, 1995:43-49; Field, 1995:77-78; Ellison \& Farnsworth, 1996:556-557; Mimura et al., 2007:690; Nicholls \& Cazenave, 2010:1518-1519).

Climate change strengthens the range of natural aggressions little manageable at the scale of the Lesser Antilles and adds extra pressure to the threats already faced by mangroves (Field, 1995:79). We will discuss only two aspects: sea level rise and hurricanes.

Mangroves in the Lesser Antilles and the elevation of the sea level. During the XXI ${ }^{\text {th }}$ century, the sea level rise is estimated to be between 30 and $180 \mathrm{~cm}$, depending on the calculation methods and assumptions (efficiency measures to limit emission of greenhouse gases; continued activity (business as usual) melting rate of Greenland and Antarctica glaciers; melting rate affecting the Arctic Ocean, etc.). (Mimura et al., 2007:694-698; Nicholls \& Cazenave, 2010:1518).

Meanwhile, two aspects need to draw our attention: the spatial distribution of mangroves swamps in the world throughout the Holocene period, and the progress in the field of geographic information systems. These two issues lead to the conclusion that (subject to adaptation phenomena and/ or topographical features) an increase of average sea level between 100 and $200 \mathrm{~cm}$ over the next 100 years would likely result in the disappearance of most areas coastal ecosystems as mangroves (contra Snedaker, 1995:43-44). The low islands would be primarily affected, unless progress is slow and allows the adaptation of mangroves in "shelter mode" and without relying on other effects related to the increase in sea level (salinity, wave energy hurricanes, tropical waves, sediment transport smothering plants, etc.) (Ellison \& Stoddart, 1991:161-162; Nicholls \& Cazenave, 2010:1518; Menon et al., 2010:1601-1602).

Extrapolating data recalled by Menon et al. (2010) and based on a scenario of one meter rise in sea level, more than $50 \%$ of coastal mangroves disappear (Menon et al., 2010:1602). It is possible to have differentiated effects: on the low islands (American and British Virgin Islands, Anguilla, Saint-Martin, Saint-Barthelemy and the Grenadines), mangroves would disappear entirely because they cannot sufficiently get back towards the interior of land. However, on the high islands, the effect of the sea level rise could be weaker due to the phenomenon of accretion of mangroves inward. In other words, very empirically, the estimated area of mangroves in the Lesser Antilles could decrease from 8000 ha currently to less than 3000 ha just because of the raising level of the sea.

Mangroves in the Lesser Antilles, hurricanes and storm surges.
The Lesser Antilles are an area of hurricanes. Their intensity could increase by 2 to $10 \%$, as well as the potential for heavy rainfall in tropical cyclones (about 15 to $20 \%$ additional rainfall near the heart of cyclones within $100 \mathrm{~km}$ ).

Practically, hurricanes impact the mangroves in many ways. Mangroves may suffer damage: trees can thus be torn, or, if they are not pulled, they can die a few months after the episode because of the cyclone damage suffered by their aerial roots (Odum et al., 1982:77). Then the mangrove species do not react in the same way to cuts: unlike Avicennia, the branches of Rhizophora are no longer growing once they are broken. Because these two species constitute the bulk of the mangroves of the Lesser Antilles, it can result from hurricanes a local reduction of the presence of a species (Rhizophora) compared to the other. Lastly, cyclones can smother mangrove with sediments mobilized by floods (Ibid., 77).

The island of Grenada provides a recent example (2004) of the devastating effects of a hurricane on mangroves (OECS, 2005:60-70).

Tropical waves, frequent rains, and rains associated with cyclones are also likely to increase the occurrence of floods damaging to mangroves (smothering, decreased salinity, mobilization of pollutants). In the case of flooding or brutal siltation, large areas of mangroves are disappearing (Odum et al., 1982:12, 77).

\subsubsection{Mangroves play a particular ecosystemic role in the Lesser Antilles}

This issue is well documented in scientific literature (especially, Odum et al., 1982:26-39, 74-76; Gilbert \& Janssen, 1998:326-333; Moberg \& Rönnbäck, 2003:2934; Millenium Ecosystem Assessment, 2003:53-60; Ellison, 2008:4-10; Farley et al., 2010:41-42).

Ecosystem functions have been highlighted in the 1980s (see, Odum et al., 1982:40-76; Costanza and Folke, 1996:26; Costanza et al., 1997; Tab.1) and developed in the early 1990s (FAO, 1994:78-80). The types of services provided by mangroves that recalled by several authors (see: Barbier, 2007:183; Table 1; Farnley et al., 2010:42; Sandilyan \& Kathiresan, 2012:3526-3538), are various from marine resources to protection against hurricanes and tsunamis, passing through restoring the quality of coastal waters and biodiversity. We do retain here two (Barbier, 2007:200) concerning marine resources and protection against major disturbances such as cyclones and tsunamis.

\section{Mangroves and protection against cyclones and tsunamis.}

The protective role of mangrove swamps in the defense against the sea was considered quite early (Odum et al., 1982:74, and after the tsunami of December 2004 in the Indian Ocean: United Nations, 2006:11, 45, 72). Concerning the Maldives, the UNEP suggests to strengthen the resilience of the coastal zone by planting a mangrove area: " a deep enough band (>20-30 m) of mangrove vegetation can absorb considerable amounts of wave energy and protect the coast beyond, while also sustaining very productive fisheries; mangroves tend to grow in and around tidal mud-flats, estuaries and lagoons"( United Nations, 2006:72). 
Regarding to the role of mangroves and to the damage they have suffered since the 1960s, this catastrophe also made economists wonder more precisely about how an economic value could be assigned to wetlands ecosystems. This can be done by supporting fishing activities or by their role in the protection against cyclones, tropical waves and tsunamis (Barbier, 2007:204-210; Das et al., 2009:7358). More than the inherent value, this "ecosystem service" would give to the mangroves an additional economic value which might count among the other uses of the coastal zone (Barbier, 2007:201204; Costanza et al., 2008:246).

Mangroves and marine resources. Mangroves provide habitat for terrestrial and marine wildlife. Their importance in terms of fish population, with the notion of ecosystem since the 1970s-1980s (Lindall et al., 1973, quoted by Robertson \& Duke, 1987:193; United Nations, 1980:45; Christensen, 1983:6-7 ; Robertson \& Duke, 1987:202203), is gradually identified and quantified since the 1990s (Rönnbäck, 1999:245-248; Barbier, 200:47-49; Mumby et al., 2004:533) It seems (Mumby et al., 2004:535) that the presence of mangroves increases the biomass of many commercial species found in the Caribbean Sea. This can be explained by two hypotheses: on the one hand, when the mangrove area is near a reef, fish benefit from the augmentation of nutrients from mangrove; on the other hand, the mangrove is an intermediate nursery habitat between herbarium and reefs which increases the survival rate of juveniles.

In the same context, a positive linear and relatively strong correlation $\left(r^{2}=0.70\right)$ has been set to a larger scale (Gulf of California) between the quantities of fish taken by fishermen and the surface and coastline of mangroves. This suggests an important role for breeding area or nursery (Aburto-Oropeza et al., 2008:10456-10458).

In a nutshell, mangroves are really useful to the islands of the Lesser Antilles that are subject to these specific threats. Yet, the Lesser Antilles do not seem to protect them as deserved.

\section{MAN AND MANGROVES IN THE LESSER ANTILLES: THE THREATS' PARADOX}

One understands that the Lesser Antilles are helpless against natural threats weighing on the mangroves. The paradox is that the inhabitants of the Lesser Antilles also threaten "their" mangrove despite the importance of ecosystem services they might be expected to enable. In fact, as pointed by Holling and Sanderson in a more general context (Holling \& Sanderson, 1996:57): "It has never been more important to understand the conjunction of human and natural systems, and the nature of their interactions. Our world is defined by the management of natural systems by human systems, which represents radical change from historical condition of humans being defined by their environments, their grand structuring cycles (plagues, economic epochs), and their slowly changing local ways of living (cultures). [...] The systemic effect of global environment change will leave no large landscapes untouched by human hands".

In an attempt to classify 20 types of major threats which loom over 24 major categories of marine ecosystems in the world, Halpern et al. (2007) recalled that the coastal development, the direct human action, the coastal engineering, the aquaculture and the rise of sea level are the main threats against mangroves (Halpern et al., 2007:13041305; Tab.1).

Following Alongi (2002), the most important danger threatening mangroves in the 2020s or thereabout could be deforestation, aquaculture in ponds, over-exploitation of timber and overfishing (Alongi, 2002:342, 346, Tab.5) (See Table 2).

However these classifications of threats do not seem to fit the Lesser Antilles (Forster et al., 2011:652-653). As indicated in the introduction: the small size of the islands "majorizes" the role of mangroves and should make easier the implementation of preservation actions on a local level. But, on the contrary, in the Lesser Antilles, the most serious threats are beyond local action (earthquakes, volcanoes, hurricanes, tsunamis, climate change), and the ones that could be handled by the local action (deforestation, household effluents, agriculture, urbanization, tourism, etc.) are, paradoxically, hardly well handled.

The direct or indirect role of the man in the degradation of mangroves is well characterized (Ellison \& Farnsworth, 1996:552-558; Halpern et al., 2007:1302).

In the Caribbean, the development of human activity had several stages that led to an extension of the colonization, then to the densification of the land occupation. Lugo et al. (1981:320, Tab.2) synthesize each step as follows: "The period from the colonial times to the present can be divided into four eras: the era of early settlement when farming activities

Table 2. Threats to mangrove forests in the world in 2025, according to Alongi (2002).

Tabela 2. Ameaças às florestas de manguezais no mundo em 2025, segundo Alongi (2002).

\begin{tabular}{l|l|l}
\hline \multicolumn{1}{c|}{ High-level threats } & \multicolumn{1}{c|}{ Intermediate threats } & \multicolumn{1}{c}{ Low-level threats } \\
\hline Deforestation & Alteration of hydrology & Oil pollution \\
\hline Pond aquaculture & Global warming & Thermal pollution \\
\hline Overexploitation of fish and shellfish & Eutrophication & $\begin{array}{l}\text { Tourism } \\
\text { Noise pollution }\end{array}$ \\
\hline
\end{tabular}

Source : Alongi, D.M. (2002) - Present state and future of the world’s mangrove forests. Environmental Conservation, 29(3):331 - 349; p 340 , Tab.5. 
were not intense (1493-1630); the era of extensive monocultures (1630-1880's); the era of economic collapse whose beginning is coincident with the abolition of slavery (1880's-1940's); ad the era of increasing energy use (from the forties to the present)." The most of the decrease of mangroves is attributable to human activity (Ellison \& Farnsworth, 1996:552), however this does not necessarily mean that economic development, symbolized by long-term growth of gross domestic product per capita, leads to a reduction of the mangrove (Barbier and Cox, 2003:429, although their study did not focus on time series, but the cross-sectional analysis at a given time on a set of 89 countries).

These disturbances due to men could be classified into four categories: extractive uses of mangrove trees and fauna, pollution, destruction of mangroves associated with reclamation for non-extractive uses and impacts of climate change (Ellison \& Farnsworth, 1996:552). Without disputing this typology, we chose here another distinction between the natural disturbances (volcanic eruptions, earthquakes, tsunamis), even influenced by human behaviour (climate change), and human disturbances (traditional and modern). This presentation seems better suited to the Lesser Antilles because it distinguishes between factors that may be controlled in a local context and factors that are out of the control of small territories, whatever resources they have.

\subsection{Human traditional disturbances: deforestation and household effluents}

Anthropogenic damages to mangroves seem to be old (Odum et al., 1982:77-84; Ellison \& Farnsworth, 1996:552558). However, the analysis in terms of ecosystems and the statistical measure of damages do not go back beyond 1970, as evidenced by scientific literature (Linden \& Jernelov, 1980:86-88; Lugo, 1980:65-72; Odum et al., 1982:26-39) or the mobilization of international bodies (United Nations, 1971).

For many years, mangroves have been exploited by indigenous and these uses did not trouble their ecologic characteristics, because damages remained below the natural abilities of regeneration (Lugo et al., 1981:320, Tab.2; Ellison \& Farnsworth, 1996:552-553). Since the XVII ${ }^{\text {th }}$ century, the traditional human actions against mangroves can be divided in two types in the Lesser Antilles: timber exploitation and household pollution.

\subsubsection{Deforestation}

The traditional deforestation to get fuelwood, charcoal, saw timber or other products such as tannin has widely decreased.

Usually realized at small-scale, they do not cause a decrease in the surface occupied by the mangrove swamps. Nevertheless, individually speaking, the effect on trees is noticeable because, as we say above, the Rhizophora (Rhizophora spp.) do not grow back after cutting unlike the Avicennia (Avicennia spp.) (Ellison \& Farnsworth, 1996:552).

St.Lucia, for instance, knows this kind of traditional deforestation, especially in the mangrove forest of Mankoté (South-East), which is the largest of the 18 mangroves of the island with 60 ha (FAO, 2005:5).
Mankoté mangrove is a marine reserve since 1986 (Fisheries Act, 1986), and then it became a "Ramsar» site in 2002 (wetland of international importance under the Convention of Ramsar (United Nations, 1971)). Under the Ramsar Convention, the Caribbean Regional Wetlands Initiative has also been launched in 2010. St. Lucia took part in order to promote the effective implementation of measures to protect wetlands in the region.

In Martinique, wood from mangroves was still used by local industries (distilleries, lime kilns, dyeing nets, etc.) in the forties especially "for heating plants and tannin" (Revert, 1949:174). However, this use has disappeared.

\subsubsection{Household effluents and waste dumping}

Mangroves household pollution has not really been studied before the early nineties (Odum, 1982:74; Ellison \& Farnsworth, 1996:554). However, we note that this pollution, which can be described as voluntary or direct from individuals, usually affects mangroves having already suffered from other damages. These mangroves already degraded somehow provide a new "service" to the populations as free garbage dump. Household pollution extends the initial damage and may foreshadow a change for final destination of the areas concerned for reasons of sanitation.

It is the case for example of the Saint-Lucian mangroves which are waste dumps (and are still used for charcoal) despites the Fisheries Act of 1986 that had classified marine reserves (Walker, 2006:106-107). Although mangroves of Mankoté and Blackbay are known to hold garbage, it is the site of Volet which suffers the most from such attacks. In this mangrove, layers of leachate float on the water or accumulate in the muddy substratum, accentuating the putrid smell of the site.

\subsection{More recent human disturbances}

Nowadays, demographic pressure appears to be the greatest threat to mangroves because of urbanization, pollution induced, climate warming and competition between activities requiring the proximity to the sea (Ong, 1995:344-345). Indeed, mangrove swamps are often located in coastal or estuarine areas which are also ideal places for human settlement (Field, 1995:79). In other words, the increase of (local or tourist) population participates to the decline of mangroves (Ong, 1995:346-348). And so, in the economies with low and middle income per capita, it appears that the increasing coastal population is actually associated with a decrease of mangrove area (Barbier \& Cox, 2003:431). This pressure has however a societal component: as said earlier, mangroves have protected themselves by their inaccessibility, their unhealthiness and their darkness. They have been marginalized in the eyes of most people, and appeared in opposition to the economic and social development, instead characterized by urban planning and mobility, accessibility, safety and light.

Among human factors of disturbance, the modern ones can be divided into non definitive damages and definitive reclamation of mangroves for agriculture, aquaculture or urbanization needs (Valiela et al., 2001:807). 


\subsubsection{Replacement of mangroves: agriculture, urbanization and tourism}

In this context, mangroves disappear under voluntary or conscious action of men that aims at recovering the surfaces to develop other activities.

The economic reasoning behind this transformation of mangrove areas is as follows: except as surfaces converted to other uses, mangroves have no explicit value (Ellison \& Farnsworth, 1996:555). Unless measuring ecosystem services, the value of mangroves swamps can even be considered as negative (unhealthiness, mosquitoes, insecure areas or sites of lawlessness, etc.), keeping away tourism and other productive activities. Mangrove swamps cost a lot to communities or individuals who own them without drawing back any money. This is the core of relations between human and natural systems: systems (particularly ecosystems) where values are not expressed in money nor on time scales beyond the short term, are disadvantaged in market economies, and are therefore often undervalued or overexploited (Hanna \& Jentoft, 1996:43). Thus, from the point of view of valuation of recreational activities in coastal ecosystems, mangroves appear clearly less attractive than sandy beaches, and they generate less revenue (Ghermandi \& Nunes, 2013:2-3).

The economic valuation of mangroves after their transformation for other purposes seems proved by the positive correlation between the decrease in mangrove area and the increase of GDP per capita (Valiela et al., 1992:811; contra, as we see above, making an analysis across 89 countries, Barbier \& Cox (Barbier \& Cox, 2003:329) observe more nuanced results, according to which an increase of $10 \%$ of GDP is correlated with an increase of $6.5 \%$ of the mangrove area).

Agriculture. Since the eighties in the Lesser Antilles, there is less deforestation in order to widen agricultural land, certainly because of the decrease of agriculture in the local economy. The tendency is to use land for other destinations related to urban development. On average, the value of agricultural production in the Lesser Antilles was divided by 3.5 from 1980 to 2010 and represents today about $4 \%$ of GDP (See Table 3).

Tourism and urbanization. Having mainly replaced agriculture in the last quarter of the twentieth century, tourism in the Lesser Antilles provides a significant part in domestic income and export earnings. To the islands facing international economic obligations (i.e. obligations to obtain foreign exchange to pay for imports; equilibrium or surplus in the balance of payments; stability of the exchange rate of the currency), tourism has been for more than 15 years a source of export earnings in the Lesser Antilles (sometimes with services activities of offshore financial centers). Tourism revenues exceed an average of half of the total exports of the States of the Lesser Antilles (See Table 4).

This aspect is attested (with exceptions) by the growth in the number of tourists visiting the Lesser Antilles (See Table 5).

From these data, it is clear that civil engineering and building which directly or indirectly determine or, at least, condition the number of tourists (and hence the mediumterm economic survival of the islands) have been favored over mangrove areas: creation or expansion of airports and/ or ports for cruise ships, development of resorts, marinas, and golf courses, construction of roads and houses, insect control, solid-waste disposal, etc. (Ellison \& Farnsworth, 1996:555-556). In many cases, urban planning and land use were also made with few rules and little controls by governmental authorities (UNEP-CEP, 2000; Lewsey et al., 2004:398).

In Barbados, for instance, the case of Graeme Hall mangrove, an original area of 250 hectares in the south of the island, illustrates, along a period of two centuries, successive effects of agriculture, urbanization, and tourism. This mangrove, now reduced to 7 hectares was degraded irreversibly despite the ban on cuts during the 1970s, the ban on hunting in 1981, the public management (Barbados

Table 3. Agricultural products of each independent country of the Lesser Antilles, in \% of the Gross Domestic Product (GDP).

Tabela 3. Produção agrícola de cada país independente das Pequenas Antilhas, em \% do produto interno bruto (PIB).

\begin{tabular}{l|c|c|c|c|c|c|c}
\hline \multicolumn{1}{c|}{ Country } & $\mathbf{1 9 8 0}$ & $\mathbf{1 9 8 5}$ & $\mathbf{1 9 9 0}$ & $\mathbf{1 9 9 5}$ & $\mathbf{2 0 0 0}$ & $\mathbf{2 0 0 5}$ & $\mathbf{2 0 1 0}$ \\
\hline Antigua \& Barbuda & 7,1 & 4,9 & 4,2 & 3,9 & 1,8 & 2,0 & 2,0 \\
\hline Barbados & 9,9 & 6,2 & 7,4 & 6,3 & 4,3 & 3,8 & $\mathrm{nc}$ \\
\hline Dominica & 30,7 & 27,9 & 25,0 & 18,9 & 13,9 & 13,7 & 13,2 \\
\hline Grenada & 24,7 & 17,1 & 13,4 & 10,1 & 6,0 & 3,4 & 5,3 \\
\hline St. Kitts \& Nevis & 15,9 & 9,1 & 6,5 & 5,3 & 2,1 & 2,3 & 1,7 \\
\hline St. Lucia & 14,4 & 15,2 & 14,5 & 10,2 & 7,0 & 3,8 & 3,2 \\
\hline St. Vincent \& the Grenadines & 14,3 & 19,6 & 21,2 & 14,1 & 8,5 & 6,3 & 6,9 \\
\hline
\end{tabular}

Sources : Authors, based on the World Bank data (2012) (< www.data.worldbank.org $>$ ).

Nota : Data from independent countries are only recorded by the World Bank.. $\mathrm{nc}=$ not communicated. 
Table 4. Revenues of tourism (in \% of exports of each independent country in the Lesser Antilles).

Tabela 4. Receitas do turismo (em \% das exportaçóes de cada país independente nas Pequenas Antilhas).

\begin{tabular}{l|c|c|c|c}
\hline \multicolumn{1}{c|}{ Country } & $\mathbf{1 9 9 5}$ & $\mathbf{2 0 0 0}$ & $\mathbf{2 0 0 5}$ & $\mathbf{2 0 1 0}$ \\
\hline Antigua \& Barbuda & 61,5 & 58,7 & 56,7 & 57,5 \\
\hline Barbados & 59,1 & 56,6 & 59,6 & 51,9 \\
\hline Dominica & 39,1 & 33,2 & 44,1 & 47,5 \\
\hline Grenada & 61,4 & 39,5 & 47,7 & 57,4 \\
\hline St. Kitts \& Nevis & 53,2 & 38,7 & 53,4 & 39,2 \\
\hline St. Lucia & 60,6 & 74,6 & 72,8 & 52,3 \\
\hline St. Vincent \& the Grenadines & 38,9 & 45,7 & 51,9 & 47,4 \\
\hline
\end{tabular}

Sources : Authors, based on the World Bank data (2012) (< www.data.worldbank.org >).

Nota: Data from independent countries are only recorded by the World Bank.

Table 5. Tourist arrivals by air in the Lesser Antilles from 1990 to 2011 (in thousands).

Tabela 5. Chegadas de turistas por via aérea nas Pequenas Antilhas 1990-2011 (em milhares).

\begin{tabular}{l|c|c|c|c|c|c}
\hline Pays & $\mathbf{1 9 9 0}$ & $\mathbf{1 9 9 5}$ & $\mathbf{2 0 0 0}$ & $\mathbf{2 0 0 5}$ & $\mathbf{2 0 1 0}$ & $\mathbf{2 0 1 1}$ \\
\hline Anguilla (UK) & 31,2 & 38,5 & 43,8 & 62,1 & 62,0 & 65,8 \\
\hline Antigua \& Barbuda & 184,2 & 191,4 & 236,7 & 245,4 & 231,3 & 241,3 \\
\hline Barbados & 432,1 & 442,1 & 544,7 & 547,5 & 532,2 & 567,7 \\
\hline British Virgin Islands (UK) & $\mathrm{nc}$ & $\mathrm{nc}$ & 281,1 & 337,1 & 330,3 & 277,0 \\
\hline Dominica & 45,1 & 60,5 & 69,6 & 79,3 & 76,5 & 75,5 \\
\hline Grenada & 76,4 & 108,0 & 128,9 & 98,5 & 106,2 & 116,4 \\
\hline Guadeloupe (FR) & $\mathrm{nc}$ & $\mathrm{nc}$ & 807,0 & $\mathrm{nc}$ & $\mathrm{nc}$ & $\mathrm{nc}$ \\
\hline Martinique (FR) & $\mathrm{nc}$ & $\mathrm{nc}$ & 526,3 & 484,1 & 476,5 & 495,3 \\
\hline Monserrat (UK) & 12,8 & 17,7 & 10,3 & 9,7 & 4,0 & 5,4 \\
\hline Saba (NL) & $\mathrm{nc}$ & $\mathrm{nc}$ & 9,1 & 11,5 & 12,3 & $\mathrm{nc}$ \\
\hline St.Eustatius (NL) & $\mathrm{nc}$ & $\mathrm{nc}$ & 8,9 & 20,4 & 6,7 & $\mathrm{nc}$ \\
\hline St.Kitts \& Nevis & 72,5 & 78,0 & 73,1 & 126,9 & $\mathrm{nc}$ & $\mathrm{nc}$ \\
\hline St.Lucia & 146,6 & 232,2 & 269,9 & 317,9 & 305,9 & 212,5 \\
\hline St.Maarten (NL) & $\mathrm{nc}$ & $\mathrm{nc}$ & 432,3 & 467,9 & 443,1 & 424,3 \\
\hline St.Vincent \& the G. & 54,5 & 60,2 & 72,9 & 95,5 & 72,5 & 73,9 \\
\hline US Virgin Islands (US) & $\mathrm{nc}$ & $\mathrm{nc}$ & 545,9 & $\mathrm{nc}$ & 691,2 & 679,0 \\
\hline
\end{tabular}

Source: Authors, based on data issued from the Caribbean Tourism Organization (CTO) and the Economic Commission for Latin America and the Caribbean (ECLAC) (2012).

Nota : these data refer only to non-nationals arriving by air. $\mathrm{nc}=$ not communicated. 
National Trust) (Parker et al., 1998), and the entry in 2005 of the site as a wetland of international importance (List of Wetlands of International Importance) under the Ramsar Convention (United Nations, 1971). The site is now contained in an urban area and tourist accommodations in the south of the island. Nevertheless, the classification of the site under the Ramsar Convention looks like a tourist argument, as well as the role of the Sanitation Department, which is in charge of mosquito control in the mangrove since 1920 and helps protect people and today tourism against the harmful effects of the mangrove.

At Bequia (archipelago of the Grenadines, St. Vincent and the Grenadines), the creation of the new airport, opened to traffic in 1992, has destroyed mangrove Paget Farm. On Prune Island (archipelago of the Grenadines), the building of a tourist complex has imposed the replacement of a part of the mangrove by a coconut plantation. It is the same story for many traditional bakeries (very popular with tourists) that use the mangrove trees because of their high calorific value.

In Martinique, the extension of the International airport (1974) to accommodate the Boeing 747, the building of ports and marinas (Marin Bay; Fort-de-France Bay: container terminal of Pointe-des-Grives, marina of Etang-Z'Abricots) also led to the disappearance or reduction of mangroves, but sometimes to a local political awareness of the importance of these areas (Malsa, 2008:101-104).

In Guadeloupe, the facilities of the Port of Pointe-à-Pitre and the industrial area of Jarry grew by infilling part of the mangrove swamps of Petit Cul de Sac Marin.

With the recent expansion of the port of Pointe-à-Pitre ( 45 ha of additional embankments; increased in draft from 11 to 17 meters), the balance between environmental protection and economic development and employment "on an island infested with unemployment" (CNDP-CPDP, 2012:71) raise fears of damage to mangroves, despite the pledges of the Port Authority during the public inquiry (Ibid., 71-74, 84).

In St.Lucia, the total area of the Rodney Bay Marina is approximately 500 hectares. This marina was developed in the seventies by dredging and excavation of an area of mangrove which have destroyed an important ecosystem while vessels operating conditions have amplified the phenomenon (Lewsey et al., 2004:398; Government of St. Lucia, 2002:12). Purchased in 2007 by an international operator (Island Global Yachting), the marina has been rehabilitated (dredging to welcome "megayachts" up to 80 meters long and 5 meters draft; installation of new floating docks; reorganization of boatyard capabilities).

\subsubsection{New damages on mangroves.}

The voluntary or conscious action of man to transform mangroves swamps and give land to other uses has decreased, as seems to confirm the slowdown of mangrove disappearance since 2000. Perhaps, the inhabitants of the Lesser Antilles are more aware of the intrinsic value of mangroves and especially of the ecosystem services. Yet indirect damages remain numerous: sewage and runoff, fertilizers, pesticides, insecticides, hydrocarbons and organochlorine compounds from urbanization, agriculture, urban activity or leisure, etc. (Fernandez et al., 2007:1682-1684).
Hydrocarbons. Apart from oil extraction activities, shipwrecks and oil spills at sea contribute to the degradation of mangroves. The problem was identified in the early sixties (Ellison \& Farnsworth, 1996:553). Hydrocarbon toxicity, when staying in the mangroves swamps, has been demonstrated: more than $96 \%$ of the seedlings of Avicennia marina die in contact with the crude oil in the space of 14 days (Grant et al., 1993). However, according to Burns et al., 1993, between 24 and 31 accidental spills of annual crude oil directly pollute the Caribbean island mangroves, whereas 20 years or longer is required for deep mud coastal habitats to recover from the toxic impact of catastrophic oil spills. This is due to the long-term persistence of oil trapped in anoxic sediments.

With the Cartagena Convention 1983 (United Nations, 1983a; United Nations, 1983b), the Caribbean countries have taken soon provisions of international law to prevent and to fight against pollution by hydrocarbons. Many other legal instruments of cooperation have been implemented in the region (Singh \& Mee, 2008:275-280).

Agriculture. In the last thirty years, the importance of agriculture has declined in the economies of the Lesser Antilles (Tab. 3). However, this sector still represents a source of pollution because of pesticides or because of the persistence in the environment of such products used in the past. The use of these products, fertilizers and pesticides, has increased since the early eighties (Rawlins et al., 1998:667) despite the decline in agriculture.

The fertilizing products spread on the ground go more or less rapidly to the marine environment according to the geomorphology of the islands, limestone or volcanic, and their retentive capacity (Rawlins et al., 1998:660, 666). In this middle, they increase its inorganic salt content causing loss of biodiversity and more generally a modification in the structure of aquatic communities. Pesticides follow the same path, but as they are persistent organic pollutants, they induce more adverse effects to public health and the animal environment linked to bioaccumulation in the food chain.

Heavy metals and organochlorines. Regional comparison in terms of heavy metals and organic compounds is difficult in particular because of the scarcity or lack of homogeneity in the methods of data collection. Despite these difficulties some harmful pollutants have been identified in mangrove mud (for example, sodium hydroxide associated with traces of bauxite in the U.S. Virgin Islands).

More recently, besides Petroleum hydrocarbons and Polycyclic aromatic hydrocarbons (PAH), some heavy metals' presence (especially $\mathrm{Pb}, \mathrm{Zn}, \mathrm{Cu}, \mathrm{Cd}$ ), Organochlorine pesticides, Polychlorinated biphenyls (PCB) used since the thirties, and macro-waste have also been identified in the coastal zone in the Lesser Antilles (Fernandez et al., 2007:1687-1690).

Straddling on the issues of household pollution and impact of tourism, it should be noted here the pollution caused by recreational boating. That pollution is a relatively recent issue in the Lesser Antilles, because of increased standards of living and the orientation of the local economies towards tourism. 
Antifouling paints with tin on ship hulls have been widespread in the sixties (Dafforn et al., 2011:454). Their toxic effects on the marine environment were highlighted in the eighties (Ibid., 456-457), leading to a total ban twenty years later (2008). Other more recent antifouling, acting as photosynthetic inhibitor, have also proven the risks of contamination to the marine environment (Carbery et al., 2006:636-640). This pollution is mainly concentrated in the marinas. It includes various contaminants (metals and $\mathrm{PAH}$ ) and contamination from different sources (gas station, ship repair, fairings, lead keels, etc.) which are trapped in the sediment and hence in the mangrove swamps. This pollution adds up to existing contaminants from land-based sources (agricultural or urban sources, including soil leaching) and pollutes the marine environment (PCBs and pesticides) (Hinkey et al., 2005:1246-1249).

Tourism and urbanization. We have seen above the importance of tourism in the economies of the Lesser Antilles (see Table ${ }^{\circ} 5$ :Tourist arrivals by air in the Lesser Antilles from 1990 to 2011). Besides the direct impact of infrastructures, the tourism and urbanization induce indirect human damages to mangroves.

In Antigua and Barbuda, for example, there is little systematic processing of wastewater; in general, the sewage is discharged directly into the environment. Some hotels undertake to recover and to treat their effluents, but this remains marginal and often based on voluntary and contractual approaches to certification (Green Award, Blue Flag Campaign or Green Globe 21) (Lewsey et al., 2004:403). Singh \& Mee recall for instance that the Caribbean became the world leader in tourism establishments certified "Green Globe 21". This type of certification is based on compliance with certain objectives such as the elimination of waste, energy conservation, limiting water consumption, effluent treatment, etc. (Singh \& Mee, 2008:278).

In Martinique, tourism remains marginal in the economy since it officially represents less than $5 \%$ of GDP $(2 \%$ in Martinique, and $4 \%$ in Guadeloupe according to Hugounenq et al., 2007:67-70). Household and urban pollution is less due to the inflow of tourists or hotel complexes failures, than to inadequate wastewater collection systems. For example, the six towns (municipalités) surrounding the bay of Fort-deFrance are totaling more than 160,000 inhabitants, while the ten wastewater treatment plants currently in operation are planned for a little less than 140,000 inhabitants. Moreover some districts are not connected to a sewage collection system, and many houses do not have septic tanks. Effluents are discharged therefore used in the bay of Fort-de-France via the rivers. As noted above these polluted waters favor the proliferation of filamentous algae that gradually smother corals. Major garbage dumps (la Trompeuse (Fort-de-France), Céron (Sainte-Luce)) are located near the coastline and they accentuate the phenomenon by percolation or flow of leachate into the marine environment and mangroves: heavy metals, organic materials, etc.

Furthermore, in volcanic islands, main roads are often located near the coast. So their building and use (runoff, for example) may have a negative effect on coastal areas, including mangrove areas. (Besides, regardless of the location of roads, it is worth to note an interesting econometric result still on cross-sectional analysis of 89 countries by Barbier and Cox (2003): in countries of low or middle income per capita (i.e. <7000 constant U.S. \$ 1987), a negative linear correlation was found by the authors between the number of kilometres of paved roads and the area of mangroves; in other words (although this "model" is not predictive), $10 \%$ increase in the length of paved roads is correlated with a decrease in mangrove area of 3.5\% (Barbier \& Cox, 2003:427, 430); probably the introduction into the model of 3 other variables - measuring the time (not one year in cross-section but twenty years panel data), the surface of paved roads (and not only the length) and the distance from the coast road - would clarify the results and look for causal relationships rather than simple correlation; lastly, we are talking here about the direct influence of the road on mangroves and not about the influence of economic development as the underlying cause of the decline of the mangrove; indeed, other results of Barbier and Cox indicate that a growth of $10 \%$ in GDP per capita induces an increase in the mangrove area of $6.5 \%$, not a decrease...).

In Martinique (just like in Guadeloupe), this situation is enforced by the size of the car fleet (about 200,000 vehicles to 400,000 inhabitants). Traffic around the bay of Fort-deFrance is particularly dense. The motorway "A1" (between Fort-de-France and Aimé Césaire International Airport at Lamentin) that runs along the mangrove swamps knows an average traffic of more than 100,000 vehicles per day (IEDOM, 2007:2). Tropical rain washes roads regularly, and runoff water from the roadbeds get high pollution loads: hydrocarbons and polycyclic aromatic residues tires, copper, chromium, cadmium, zinc (SETRA, 2006:4) mostly flowing in the mangrove.

In Guadeloupe, the garbage dump of the Gabarre, the largest of the island, evacuates its leachates in the Grand Cul-de-Sac Marin. The Guadeloupe household and urban pollution also results from the small number of sewage treatment plants.

Generally speaking, although the Lesser Antilles islands have adopted the principles of ecosystem protection and integrated development of coastal areas (including various international conventions in this area), the implementation is not always effective. Land use policy, urban planning, building on the coastline or next to the mangroves with traditional utilizations (garbage dump, logging, etc.) still remains (Government of St. Lucia, 2002:10-16; Lewsey et al., 2004:402; Walker, 2006:22-23, 28; YWF-Kido Foundation, 2007:17-20, 47). It should be noted that, in the Lesser Antilles, the weak enforcement of some legal standards, including environmental ones lato sensu, and the mosaic of public authorities in the coastal zone are not specific to the independent islands (Forster et al., 2011:654-655). 


\section{CONCLUSION}

4.1. In summary, mangrove swamps dramatically decrease during the past thirty years in the Lesser Antilles. But methodological and statistical problems impede a good estimate of long-term evolution of that ecosystem before the nineties.

By the way, mangroves were soon disqualified because of their inaccessibility and "unhealthiness". Moreover, deprived of their traditional functions, mangroves have been progressively marginalized with economic development, tourism and the rising of living standards in small islands economies notwithstanding their positive role as an ecosystem. Highlighted since the 1980s, this role appears particularly evident in the field of marine resources and protection against hurricanes and tsunamis, but also to help restore the quality of coastal waters and biodiversity.

From these observations, we wondered about a paradox faced by the inhabitants of the Lesser Antilles. Grossly, mangrove swamps are threatened by natural phenomena and by the behaviour of population. On one hand inhabitants really cannot prevent major natural threats on their wetlands like global climate change, hurricanes, earthquakes, volcanoes or tsunamis. But on the other hand, due to their small territorial and political scale, these islands should be able to act themselves against local anthropogenic threats upon mangroves i.e. deforestation, household effluents, agriculture, urbanization, tourism, etc. Indeed, the Lesser Antilles islands have adopted the principles of ecosystem protection and integrated development of coastal areas (including various international conventions in this area). There, land use policy, urban planning, and the building on the coastline or next to the mangroves are theoretically and legally under public control. Yet that does not work: effective provisions and outcomes remain often weak against direct anthropogenic threats. We give a few typical examples illustrating the damage to mangroves in these islands today whatever the political status or the administrative organization.

4.2. In this paper, we put forward some factual observations (and assumptions) about the mangroves in the Lesser Antilles, as an aspect of contemporary relations between men and their coastal environment.

However, at this stage, the explanatory power of geography (and even history) remains relatively weak, especially in order to get the attention of administrators and planners. So, in the future, we think it would be interesting to extend this paper with an approach mainly based on some items of environmental economics.

- Actually, the protection granted to goods depends on the value of goods. So, despite international legal standards, local policies or mantras, the continuous decrease of mangrove surfaces, especially in small islands, maybe reflects a lack in the recognition of the mangroves value. In other terms, in small islands, perhaps because of narrowness of the territory, the "price" of mangroves appears lower to other values that may be more "economic" or "social" (global income, income per capita, development, employment, generalization of urban ways of life among small developing states or territories, etc.).
- Lesser Antilles inhabitants will prefer to ignore uncertainty (hurricanes, earthquakes, tsunamis), longterm effects of their actions (global warming, loss of mangroves) and problems that exceed their immediate living environment (e.g. reduction of fishery resources or other "ecosystem services": water quality, protection against floods, biodiversity, etc.). This is why the effects of permanent loss of mangrove swamps will therefore be underestimated with regard to this scale of values.

In our opinion, this aspect will bring back to broader questions: What are the local conditions of effective protection and management of mangroves ? How can the individual and social choices be managed in order to preserve the long term elements of the coastal environment of the Lesser Antilles? This leads us to a more general question of the mismanagement (if not the "tragedy", as mentioned by Garrett Hardin) of the commons and the necessity to pursue, in particular on the small territories and on the coastal zone, the implementation of special tools to integrate time, space, rules, men, nature, but also valuation and protection.

\section{REFERENCES}

Aburto-Oropeza, O.; Ezcurra, E.; Danemann, G.; Valdez, V.; Murray, J.; Sala, E. (2008) - Mangroves in the Gulf of California increase fishery yields. Proceedings of the National Academy of Sciences of the USA, 105(30):1045610459. DOI: $10.1073 /$ pnas.0804601105.

Adger, N.; Luttrell, C. (2000) - Property rights and the utilisation of wetlands. Ecological Economics, 35(1):7589. DOI: $10.1016 / S 0921-8009(00) 00169-5$.

Alongi, D.M. (2002) - Present state and future of the world's mangrove forests. Environmental Conservation, 29(3):331-349. DOI: 10.1017/S0376892902000231.

Augier, D. (2010) - Les écosystèmes marins de la Caraibe: identification, diffusion et modes de gestion. Études caribéennes, 15, Avril 2010. http://etudescaribeennes.revues.org/4343.DOI: 10.4000/ etudescaribeennes.4343.

Barbier, E.B. (2000) - Valuing the environment as input: review of applications to mangrove-fishery linkages. Ecological Economics, 35(1):47-61. DOI: 10.1016/ S0921-8009(00)00167-1.

Barbier, E.B. (2007) - Valuing ecosystem services as productive inputs. Economic Policy, 22(49):177-229. DOI : $10.1111 /$ j.1468-0327.2007.00174.x

Barbier, E.B. (2012) - A spatial model of coastal ecosystem services. EcologicalEconomics, 78:70-79. DOI: 10.1016/j. ecolecon.2012.03.015.

Barbier, E.B.; Cox, M. (2003) - Does Economic Development Lead to Mangrove Loss? A Cross-Country Analysis. Contemporary Economic Policy, 21(4):418-432. DOI: $10.1093 /$ cep/byg022.

Burns, K.A.; Garrity, S.D.; Levings, S.C. (1993) - How many years until mangrove ecosystems recover from catastrophic spills ? Marine Pollution Bulletin, 26(5):239248. DOI: 10.1016/0025-326X(93)90062-O.

Carbery, K.; Owen, R.; Frickers, T.; Otero, E.; Readman, J. (2006) - Contamination of Caribbean coastal waters by the antifouling herbicide Irgarol 1051. Marine Pollution Bulletin, 52(6):635-644. DOI : 10.1016/j. marpolbul.2005.10.013. 
Christensen, B. (1983) - Mangroves: what are they worth? Unasylva, 35(139): 2-15. Available online: http://www. fao.org/docrep/q1093e/q1093e00.htm.

CIA (2012) - World Factbook 2012. Central Intelligence Agency, Washington, DC., USA. Available online: https://www.cia.gov/library/publications/the-worldfactbook/.

CNDP-CPDP (2012) - Compte Rendu du Débat Public sur l'Extension du Port de Jarry-Guadeloupe - 5 octobre 2011 / 31 janvier 2012. 101p., Commission Nationale du Débat Public-Commission Particulière du Débat Public, Paris, France. Available online: http://www.debatpublicportguadeloupe.org/.

Costanza, R.; Folke, C. (1996) - The structure and Function of Ecological Systems in Relation to Property-Rights Regimes, pp.13-34, In: Hanna, S.; Folke, C.; Mäler, K.-G. (eds.) (1996) - Rights to Nature. Ecological, Economic, Cultural, and Political Principles of Institutions for the Environment. 298 p. Island Press, Washington DC., USA. ISBN: 978-1559634908.

Costanza, R.; d'Arge, R; de Groot, R.; Farber, S; Grasso, M.; Hannon, B.; Limburg, K.; Naeem, S.; O’Neill, R.V.; Paruelo, J.; Raskin, R.G.; Sutton, P.; van den Belt, M. (1997) - The value of the World's Ecosystem Services and Natural Capital. Nature, 387(6630):253-260. DOI: 10.1038/387253a0.

Costanza, R.; Pérez-Maqueo, O; Martinez, M.L.; Sutton, P. Anderson, S.J. Mulder, K. (2008) The Value of Coastal Wetlands for Hurricane Protection. Ambio, 37(4):241-248. DOI: 10.1579/0044 7447(2008)37[241:TVOCWF]2.0.CO;2.

CTO (2012) - Statistics \& Market Research, Caribbean Tourism Organization. Available online: http://www. onecaribbean.org/statistics/.

Dafforn,K.A.;Lewis, J.A.;Johnston,E.L.(2011)-Antifouling strategies: History and regulation, ecological impacts and mitigation. Marine Pollution Bulletin, 62(3):453-465. DOI: 10.1016/j.marpolbul.2011.01.012.

Danielsen, F; Sørensen, M.K.; Olwig, M.F.; Selvam, V.; Parish, F.; Burgess, Neil.D.; Hiraishi, T.; Karunagaran, V.M.; Rasmussen, M.S.; Hansen, L.B.; Quarto, A.; Suryadiputra, N. (2005) - The Asian Tsunami: A Protective Role for Coastal Vegetation. Science, (310)643. DOI:10.1126/science.1118387.

Das, S.; Vincent, J.R. (2009) - Mangroves protected villages and reduced death toll during Indian super cyclone. Proceedings of the National Academy of Sciences of the USA, 106(18):7357-7360. DOI: 10.1073/pnas.0810440106.

Dietz, T.; Ostrom, E.; Stern, P.C. (2003) - The Struggle to Govern the Commons. Science, 302:1907-12. DOI: $10.1126 /$ science. 1091015 .

Du Tertre, J.B. (1667) - Histoire Générale des Antilles habitées par les François. Tome II. 539 p. Thomas Jolly Editeur, Paris, France. Available online: http://gallica.bnf.fr/ ark:/12148/bpt6k114021k.

Durigon, D.; Hickey, G.M.; Kosoy, N. (2012) - Assessing national wetland policies' portrayal of wetlands: Public resources or private goods? Ocean \& Coastal Management, 58:36-46. DOI:10.1016/j.ocecoaman.2011.12.008.

ECLAC (2003) - Caribbean Tourism: Trends Policies and Impact - 1985-2002, Economic Commission for Latin America and the Caribbean, 77p., Available online: http://www.eclac.org/publicaciones/xml/4/14504/ G0765.pdf.

Ellison, A.M. (2008) - Managing mangroves with benthic biodiversity in mind: Moving beyond roving banditry. Journal of Sea Research, 59:2-15. DOI: 10.1016/j. seares.2007.05.003.

Ellison, A.M.; Farnsworth, E.J. (1996) - Anthropogenic Disturbance of Caribbean Mangrove Ecosystems: Past Impacts, Present Trends, and Future. Biotropica, 28 (4 - Part A. Special Issue: Long Term Responses of Caribbean Ecosystems to Disturbances):549-565. DOI: $10.2307 / 2389096$.

Ellison, J. C.; Stoddart, D.R. (1991) - Mangrove ecosystem collapse during predicted sea-level rise: holocene analogues and implications. Journal of Coastal Research, 7(1):151-165. Available online: http://www.jstor.org/ stable/4297812.

FAO (1948) - Forest Resources of the World. Unasylva, 2(4), FAO - Food and Agriculture Organization of the United Nations, Rome, Italy. Available at http://www.fao.org/ docrep/x5345e/x5345e00.htm

FAO (1957) - World Forest Resources - Results of the inventory undertaken in 1953. 132p., Forestry Division of FAO - Food and Agriculture Organization of the United Nations, Rome, Italy. Available online: http://www.fao.org/docrep/015/an053e/an053e00.pdf.

FAO (1958) - World Forest Inventory 1958. 156p., Forestry Division of FAO - Food and Agriculture Organization of the United Nations, Rome, Italy. Available online: http://www.fao.org/docrep/015/an054e/an054e00.pdf.

FAO (1963) - World Forest Inventory 1963. 118p., Forestry Division of FAO - Food and Agriculture Organization of the United Nations, Rome, Italy. Available online: http://www.fao.org/docrep/007/ad907t/ad907t00.htm.

FAO (1994) - Mangrove Forest Management Guidelines. 353p., FAO Forestry Paper 117. FAO - Food and Agriculture Organization of the United Nations, Rome, Italy. Available online: https://archive.org/details/ mangroveforestma034845 mbp.

FAO (2001) - Global Resources Assessment 2000. FAO Forestry Paper 140, Forestry Department of FAO - Food and Agriculture Organization of the United Nations, Rome, Italy. Available online: http://www.fao.org/ docrep/004/Y1997E/Y1997E00.htm.

FAO (2005) - Global Forest Resources Assessment 2005. Thematic Study on Mangroves. Saint-Lucia. Country Profile. 11p., Forestry Department of FAO - Food and Agriculture Organization of the United Nations, Rome, Italy. Available online: http://www.fao.org/forestry/941709329cfef59a4fda7369408021849fa8a.pdf.

FAO (2007a) - The World's Mangroves 1980-2005: A thematic study in the framework of the Global Forest Resources Assessment 2005. 77p., FAO Forestry Paper 153, Forestry Department of FAO - Food and Agriculture Organization of the United Nations, Rome, Italy. ISBN: 978-9251058565.

FAO (2007b) - Mangroves of North and Central America 1980-2005: country reports. 34p., Forest Resources Assessment Working Paper 138, Forestry Department of FAO - Food and Agriculture Organization of the United Nations, Rome, Italy. Available online: ftp://ftp.fao.org/ docrep/fao/010/ai446t/ai446t00.pdf 
FAO (2010a) - Global Forest Resources Assessment 2010 - Main report.378p., FAO Forestry Paper 163, Forestry Department of FAO - Food and Agriculture Organization of the United Nations, Rome, Italy. ISBN: 978-9251066546.

FAO (2010b) - Evaluation des Ressources Forestières Mondiales 2010 - Rapport national - Guadeloupe. 58p., Forestry Paper 82, Forestry Department of FAO - Food and Agriculture Organization of the United Nations, Rome, Italy. Available online: http://www.fao.org/docrep/013/ al 518F/al518F.pdf

FAO (2010c) - Evaluation des Ressources Forestières Mondiales 2010 - Rapport national - Martinique. 54p., Forestry Paper 128, Forestry Department of FAO - Food and Agriculture Organization of the United Nations, Rome, Italy. Available online: http://www.fao.org/docrep/013/ al 563F/al 563F.pdf.

FAO (2012) - Agriculture statistics database. (FAOSTAT). FAO - Food and Agriculture Organization of the United Nations, Rome, Italy. Available online: http://faostat.fao.org/.

Farley, J.; Batker, D.; de la Torre, I.; Hudspeth, T. (2010) - Conserving Mangrove Ecosystems in the Philippines: Transcending Disciplinary and Institutional Borders. Environmental Management, 45:39-51. DOI: 10.1007/ S00267-009-9379-4.

Farnsworth, E.J.; Ellison, A.M. (1997) - The Global Conservation Status of Mangroves. Ambio, 26(6):328334. DOI: 10.2307/4314614.

Fernandez, A.; Singh, A.; Jaffé, R. (2007) - A literature review on trace metals and organic compounds of anthropogenic origin in the Wider Caribbean Region. Marine Pollution Bulletin, 54(11):1681-1691. DOI: 10.1016/j.marpolbul.2007.08.007.

Field, C.D. (1995) - Impact of expected climate change on mangroves. Hydrobiologia, 295(1-3):75-81. DOI: 10.1007/BF00029113.

Field, C.D. (1999) - Rehabilitation of Mangrove Ecosystems: An Overview. Marine Pollution Bulletin, 37(8-12):383392. DOI: 10.1016/S0025-326X(99)00106-X.

Forster, J.; Lake, I.R.; Watkinson, A.R.; Gill, J.A. (2011) - Marine biodiversity in the Caribbean UK overseas territories: Perceived threats and constraints to environmental management. Marine Policy, 35(5):647657. DOI: 10.1016/j.marpol.2011.02.005.

Froehner, S.; Scurupa Machado, K; Stefan, E.; Bleninger, T.; Cordova da Rosa, E.; de Castro Martins, C. (2012) Occurrence of selected estrogens in mangrove sediments. Marine Pollution Bulletin, 64:75-79. DOI: 10.1016/j. marpolbul.2011.10.021.

Ghermandi, A.; Nunes, P.A.L.D. (2013) - A global map of coastal recreation values: Results from a spacially explicit meta-analysis. Ecological Economics, 86:1-15. DOI: 10.1016/j.ecolecon.2012.11.006.

Gilbert, A.J.; Janssen, R. (1998) - Use of environmental functions to communicate the values of a mangrove ecosystem under different management. Ecological Economics, 25(3):323-346. DOI: 10.1016/S09218009(97)00064-5.

Government of Saint-Lucia (2002) - Coastalzonemanagement in Saint Lucia: Issues paper. Coastal Zone Management Project, Ministry of Agriculture, Forestry and Fisheries,
24 p. Castries. St.Lucia. Available online: http://www. uvm.edu/ -jfarley/st\%20lucia/CZMIssuesPaper.pdf.

Government of Saint-Lucia (2012) - National Report on the Implementation of the Ramsar Convention on Wetlands. 11th Meeting of the Conference of the Contracting Parties, June 2012, 30 p. Available online: http://www. ramsar.org/pdf/cop11/nr/cop11-nr-saintlucia.pdf.

Granek, E.; Polasky, S.; Kappel, C.; Reed, D.; Stoms, D.M.; Koch, E.W.; Kennedy, C.; Cramer, L.; Hacker, S.D.; Barbier, E.B.; Aswani, S.; Ruckelshaus, M.; Perillo, G.M.; Silliman, B..R.; Muthiga, N.; Bael, D.; Wolanski, E. (2010) - Ecosystem Services as a Common Language for Coastal Ecosystem-Based Management. Conservation Biology, 24(1):207-216. DOI: 10.1111/j.15231739.2009.01355.x.

Grant, D.L.; Clark, P.J.; Allaway, W.G. (1993) - The response of grey mangrove (Avicennia marina (Forsk.) Vierh.) seedlings to spills of crude oil. Journal of Experimental Marine Biology and Ecology, 171(2):273-295. DOI: 10.1016/0022-0981(93)90009-D.

Griffin, C.; Ellis, D.; Beavis, S.; Zoleta-Nantes, D. (2013) Coastal resources, livehoods and the 2004 Indian Ocean tsunami in Aceh, Indonesia. Ocean \& Coastal Management, 71:176-186. DOI: 10.1016/j.ocecoaman.2012.10.017.

Guarderas A.P. ; Hacker, S.D. ; Lubchenco, J. (2008) - Current Status of Marine Protected Areas in Latin America and the Caribbean. Conservation Biology, 22(6):1630-1640. DOI:10.1111/j.1523-1739.2008.01023.x.

Halpern, B.S.; Selkoe, K. A.; Micheli, F; Kappel, C.V. (2007) - Evaluating and Ranking the Vulnerability of Global Marine Ecosystems to Anthropogenic Threats. Conservation Biology, 21(5):1301-1315. DOI: 10.1111/ j.1523-1739.2007.00752.x.

Hanna, S.; Folke, C.; Mäler, K.-G. (eds.) (1996) - Rights to Nature. Ecological, Economic, Cultural, and Political Principles of Institutions for the Environment. 298 p. Island Press, Washington DC., USA. ISBN: 978-1559634908.

Hanna, S.; Jentoft, S. (1996) - Human Use of the Natural Environment: An Overview of Social and Economic Dimensions, pp.35-55, In: Hanna, S.; Folke, C.; Mäler, K.-G. (eds.) (1996) - Rights to Nature. Ecological, Economic, Cultural, and Political Principles of Institutions for the Environment. 298 p. Island Press, Washington DC., USA. ISBN: 978-1559634908.

Hardin, G. (1968) - The tragedy of the commons. Science, 162:1243-1248. DOI: 10.1126/science.162.3859.1243.

Hinkey, L.M.; Zaidi, B.R.; Volson, B ; Rodriguez, N.J. (2005) - Identifying sources and distributions of sediments contaminants at two US Virgin Islands marinas. Marine Pollution Bulletin, 50(11):1244-1250. DOI: 10.1016/j. marpolbul.2005.04.035.

Holling, C.S.; Sanderson, S. (1996) -Dynamics of (Dis) harmony in Ecological and Social Systems, pp.57-85, In: Hanna, S.; Folke, C.; Mäler, K.-G. (eds.), - Rights to Nature. Ecological, Economic, Cultural, and Political Principles of Institutions for the Environment. 298 p. Island Press, Washington DC., USA. ISBN: 978-1559634908.

Hugounenq, R.V.; Joeger, C.; Baude, J.; Simon, O.; Jacquelain, V.; Savoye, B. (2007) - L'ultrapériphéricité définit-elle un modèle de croissance? 123 p. Institut National de la Statistique et des Etudes Economique, Paris, France. Available online: http://www.insee.fr/fr/insee_regions/ reunion/themes/cerom/cerom3/cerom3.pdf. 
IEDOM (2007) - Le développement du transport urbain et interurbain en Martinique. Note expresse de l'Institut d'Emission des Départements d'Outre-Mer, 48:1-7. Available online: http://www.iedom.fr/IMG/pdf/ne48_eclairage_ transport_interurbain_martinique.pdf.

Imbert, D.; Rousteau, A.; Scherrer, P. (2000) - Ecology of Mangrove Growth and Recovery in the Lesser Antilles: State of Knowledge and Basis for Restoration Projects. Restoration Ecology, 8(3):230-236. DOI: 10.1046/j.1526100x.2000.80034.x.

ISME (1992) - Charter for Mangroves. International Society for Mangrove Ecosystems. Available online: http://www. mangrove.or.jp/isme/english/img/charter.pdf.

Klein, J. (2003) - La mangrove: un modèle de développement touristiquedurable?Availableonline:http://geoconfluences. ens-lyon.fr/doc/typespace/littoral1/LittorScient2.htm.

Lanly, J. (1982) - Tropical Forest Resources. FAO Forestry Paper n³0. Rome, Italy. Available online: http://www. ciesin.columbia.edu/docs/002-113/002-113.html.

Lesales, T. (2007) - L'inégalité des territoires insulaires de la Caraïbe face aux menaces volcaniques. Etudes caribéennes, 7:2-7. Available online: http://etudescaribeennes.revues. org/316. DOI: 10.4000/etudescaribeennes.316.

Lewsey, C.; Cid, G.; Kruse, E. (2004) - Assessing climate change impacts on coastal infrastructure in the Eastern Caribbean. Marine Policy, 28(5):393-409. DOI: 10.1016/j.marpol.2003.10.016.

Lindén, O.; Jernelöv, A. (1980) - The mangrove swamp: An ecosystem in danger. Ambio, 9(2):81-88. Available online: http://www.jstor.org/stable/4312537.

Lourie, S.A.; Vincent, A. C.J. (2004) - Using Biogeography to Help Set Priorities in Marine Conservation. Conservation Biology, 18(4):1004-1020. DOI: 10.1111/ j.1523-1739.2004.00137.x.

Lugo, A.E. (1980) - Mangrove ecosystems: Successional or steady state?. Biotropica, 12 (1 Suppl.: Tropical Succession): 65-72. DOI: 10.2307/2388158.

Lugo, A.E.; Schmidt, R.; Brown, S. (1981) - Tropical Forests in the Caribbean. Ambio, 10(6):318-324. Available online: http://www.jstor.org/stable/4312728.

Malsa, G. (2008) - L'Ecologie ou la Passion du vivant - 40 ans d'écrits écologiques. 288 p. L'Harmattan, Paris, France. ISBN: 978-2-296-05054-9.

Menon, S.; Soberón, J.; Li, X.; Townsend Peterson, A. (2010) - Preliminary global assessment of terrestrial biodiversity consequences of sea-level rise mediated by climate change. Biodiversity and Conservation, 19(6):1599-1609. DOI: $10.1007 / \mathrm{s} 10531-010-9790-4$.

Millennium Ecosystem Assessment (2003) - Ecosystems and Human Well-being. A Framework for Assessment. 266 p. Island Press, Washington, DC, USA. ISBN: 9781559634021.

Mimura, N.; Nurse, L.; McLean, R.F.; Agard, J.; Briguglio, L.; Lefale, P.; Payet, R.; Sem, G. (2007) - Small islands. In: M.L. Parry, O.F. Canziani, J.P. Palutikof, P.J. van der Linden and C.E. Hanson (eds.), Climate Change 2007: Impacts, Adaptation and Vulnerability. Contribution of Working Group II to the Fourth Assessment Report of the Intergovernmental Panel on Climate Change, pp.687-716, Cambridge University Press, Cambridge,
U.K. ISBN: 9780521705974. Available online: http://www.ipcc.ch/pdf/assessment-report/ar4/wg2/ar4wg2-chapter16.pdf.

Moberg, F.; Rönnbäck, P. (2003) - Ecosystem services of the tropical seascape: interactions, substitutions and restoration. Ocean \& Coastal Management, 46:27-46. DOI: 10.1016/S0964-5691(02)00119-9.

Monnier, P. (1828) - Description nautique des côtes de la Martinique. 185p., Imprimerie Royale, Paris, France. Available online: http://www.manioc.org/patrimon/ HASH015ca29ec61f80e7f57053e6.

Mumby, Peter J.; Edwards, Alasdair J.; Arias-González, J. Ernesto; Lindeman, Kenyon C.; Blackwell, Paul G.; Gall, Angela; Gorczynska, Malgosia I.; Harborne, Alastair R.; Pescod, Claire L.; Renken, Henk; Wabnitz, Colette C. C.; Llewellyn, Ghislane (2004) - Mangroves enhance the biomass of coral reef fish communities in the Caribbean. Nature, 427(6974):533-536. DOI: 10.1038/ nature 02286.

Nations Unies (2000). Résolution S-22-2 adoptée par l'Assemblée Générale. Déclaration et progrès accomplis dans l'application du Programme d'action pour le développement durable des petits Etats insulaires en développement et initiatives en la matière. New-York, 28 septembre 2000. Available online: http://daccessdds-ny.un.org/doc/UNDOC/GEN/N00/424/13/PDF/ N0042413.pdf?OpenElement.

Nicholls, R.J.; Cazenave, A (2010) - Sea-Level Rise and Its Impact on Coastal Zones. Science, 18 June 2010, 328:1517-1520. DOI: 10.1126/science.1185782.

Odum, W.E.; McIvor, C.C.; Smith III, T.J. (1982) - The ecology of the mangroves of South Florida: A community profile. U. S. Fish \& Wildlife Service, Office of Biological Services, Washington, D.C. FWS/OBS-81/24. 144 pp. Available online: http://www.nwrc.usgs.gov/techrpt/8124.pdf.

OECS (2005) - Grenada: Macro-Socio-Economic Assessment of the damages caused by Hurricane IVAN-Sep 2004. 138 p. Organisation of Eastern Caribbean States. Castries, St.Lucia. Available online: http://www.gov.gd/egov/docs/ reports/Ivan-Report-07-09-04.pdf.

Ong, J. E. (1995) - The ecology of mangrove conservation and management. Hydrobiologia 295(1-3):343-351. DOI: $10.1007 / \mathrm{BF} 00029141$.

Ostrom, E.; Janssen, M.A.; Anderies, J.A. (2007) - Going beyond panaceas. Proceedings of the National Academy of Sciences of the USA, 104(39):15181-15187. DOI: $10.1073 /$ pnas.0701886104.

Ostrom, E. (2007) - A diagnostic approach for going beyond panaceas. Proceedings of the National Academy of Sciences of the USA, 104 (39):15181-15187. DOI: 10.1073/ pnas.0702288104.

Perrings, Ch. (2007) - Future challenges. Proceedings of the National Academy of Sciences of the USA, 104 (39):1517915180. DOI: 10.1073/pnas.0701957104.

Rawlins, B.G.; Ferguson, A.J.; Chilton, P.J.; Arthurton, R.S.; Rees, J.G.; Baldock, J.W. (1998) - Review of agricultural pollution in the Caribbean with particular emphasis on small island developing states. Marine Pollution Bulletin, 36(9):658-668. DOI: 10.1016/S0025326X(98)00054-X. 
Revert, E. (1949) - La Martinique - Etude géographique (Thèse de doctorat en géographie). 560p., Nouvelles Editions Latines, Paris, France. Available online: http://classiques.uqac.ca/classiques/revert_eugene/ martinique/martinique.html.

Robertson A, I.; Duke N.C. (1987) - Mangroves as nursery sites: comparisons of the abundance and species composition of fish and crustaceans in mangroves and other nearshore habitats in tropical Australia. Marine Biology, 96:193-205. DOI: 10.1007/BF00427019.

Rönnbäck, P. (1999) - The ecological basis for economic value of seafood production supported by mangrove ecosystems. Ecological Economics, 29(2):235-252. DOI: 10.1016/S0921-8009(99)00016-6.

Roth, L.C. (1992) - Hurricanes and mangrove regeneration: Effects of Hurricane Joan, October 1988, on the vegetation of Isla de Venado, Bluefields, Nicaragua. Biotropica 24(3):375-384. DOI: 10.2307/2388607.

Saffache, P. (2002) - Les mangroves caribéennes: des milieux fragiles nécessitant une politique de gestion et de protection adaptée. La Revue Forestière Française, 4:329336. DOI: $10.4267 / 2042 / 4925$.

Saffache, P.; Angelelli, P. (2010) - Integrated Coastal Zone Management in small islands: A comparative outline of some islands of the Lesser Antilles. Revista da Gestão Costeira Integrada, 10(3):255-279. DOI: 10.5894/rgci228.

Sandilyan, S.; Kathiresan, K. (2012) - Mangrove conservation: a global perspective. Biodiversity Conservation, 21:35233542. DOI: 10.1007/s10531-012-0388-x.

Sebastiani, M.; González, S.E.; Castillo, M.M.; Alvizu, P.; Oliveira, M.A.; Pérez, J.; Quilici, A.; Rada, M.; Yáber, M.C.; Lentino, M. (1994) - Large-scale shrimp farming in coastal wetlands of Venezuela, South America: Causes and consequences of land-use conflicts. Environmental Management, 18(5):647-661. DOI: 10.1007/BF02394631.

SETRA (2006) - Calcul des charges de pollution chronique des eaux de ruissellement issues des plates-formes routières. Note d'information du Service d'Etudes Techniques des Routes et Autoroutes (SETRA) du Ministère français chargé de l'Equipement, 75:1-12. Available online: http://www. setra.equipement.gouv.fr/IMG/pdf/NI_EEC_075.pdf.

Singh, A.; Mee, L. (2008) - Examination of policies and MEAs commitment by SIDS for sustainable management of the Caribbean Sea. Marine Policy, 32(3):274-282. DOI: 10.1016/j.marpol.2007.06.004.

Snedaker, S.C. (1995) - Mangroves and climate change in the Florida and Caribbean region: scenarios and hypotheses. Hydrobiologia, 295(1-3):43-49. DOI: 10.1007/BF00029109.

Sommer, A. (1976) - Attempt at an assessment of the world's tropical moist forest. Unasylva, 112-113:5-27. Available online: http://www.fao.org/docrep/k0050e/k0050e03.htm.

Thibault de Chanvalon, J.B. (1763) - Voyage à la Martinique, contenant diverses observations sur la physique, l'histoire naturelle, l'agriculture, les moeurs et les usages de cette isle, faites en 1751 \& dans les années suivantes. Lu à l'Académie royale des sciences de Paris en 1761.335p., C.J.B. Bauche Editeur, Paris, France. Available online: http://gallica.bnf. fr/ark:/12148/bpt6k102016b

UNEP-CEP (2000) - An Overview of Land Based Sources of Marine Pollution. Caribbean Environment Programme
Marine Issues. United Nations Environment Programme. Available online: http://www.cep.unep.org/issues/lbsp.html.

UNEP-CEP (2002) - Caribbean Environment Programme, Marine Issues. United Nations Environment Programme. Available online: http://www.cep.unep.org/issues/sub_ issues.htm.

United Nations (1971) - Convention on Wetlands of International Importance especially as Waterfowl Habitat. Ramsar (Iran), 2 February 1971. UN Treaty Series No. 14583. As amended by the Paris Protocol, 3 December 1982, and Regina Amendments, 28 May 1987. Available online: http://treaties.un.org/doc/Publication/UNTS/ Volume\%20996/volume-996-I-14583-English.pdf .

United Nations (1980) - Marine pollution implications of coastal area development. GESAMP, Reports and Studies $\mathrm{n}^{\circ} 11,112 \mathrm{p}$. Available online: http://www.gesamp.org/ data/gesamp/files/media/Publications/Reports_and_ studies_11/gallery_1227/object_1232_large.pdf .

United Nations (1983a) - Convention for the Protection and Development of the Marine Environment in the Widr Caribbean Region. Cartagena de Indias, 24 March 1983. Available online: http://www.cep.unep.org/cartagenaconvention/cartagena-convention.pdf .

United Nations (1983b) - Protocole concerning co-operation in combating oil spills in the Wider Caribbean Region. Cartagena de Indias, 24 March 1983. Available online: http://www.cep.unep.org/cartagena-convention/oilspills-protocol/oil-spills-protocol-en.pdf/view.

United Nations (2006) - After the Tsunami: Rapid Environmental Assessment. United Nations Environment Programme. ISBN: 9789280725650.

Valiela, I.; Bowen, J.L.; York, J.K. (2001) - Mangrove forests: one of the world's threatened major tropical environments. Bioscience, 51(10):807-815. DOI: 10.1641/0006-3568( 2001)051[0807:MFOOTW]2.0.CO;2.

Vallega, A. (2007) - The role of culture in island sustainable development. Ocean \& Coastal Management, 50:270300. DOI: 10.1016/j.ocecoaman.2007.02.003.

Vasques, Ricardo O'Reilly; Tonini, W.C.T.; Cuevas, J.M.; Santos, D.F.; Faria, T.A.; Falcão, F.C.; Simões, D.R.; Batista, R.L.G.; Couto, E.C.G. (2011) - Utilização das Áreas de Manguezais em Taipús de dentro (Maraú, Sul da Bahia). Revista de Gestão Costeira Integrada, 11(2):155161. DOI: $10.5894 /$ rgci205.

Walker, L.A. (2006) - Towards the development of CoastalZone Management strategy and Action Plan for St. Lucia. 163 p. Available online: http://www.un.org/depts/los/nippon/ unnff_programme_home/fellows_pages/fellows_papers/ walker_0506_stlucia.pdf.

Wilkinson, C.; Salvat, B. (2012) - Coastal resource degradation in the tropics: Does the tragedy of the commons apply for coral reefs, mangrove forests and seagrass beds ? Marine Pollution Bulletin, 64(6):10961105. DOI: 10.1016/j.marpolbul.2012.01.041.

World Bank (2012) - Country Facts from the World Bank. Washington, DC., USA. Available online: http://data. worldbank.org/.

YWF-Kido Foundation (2007) - Grenada's National Protected Areas System Capacity Development, Final Draft Plan, July 2007, 53 p. Available online: www.cbd.int/database/ attachment/?id=613. 